\title{
Pelvic Exenteration for Recurrent Rectal Cancer: A Single Institution Experience
}

\section{Rekürren Rektal Kanserlerde Pelvik Ekzantrasyon: Tek Merkez Deneyimi}

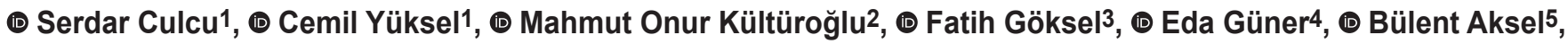 \\ (1) Lütfi Doğan1 \\ 1 University of Health Sciences Turkey, Dr. Abdurrahman Yurtaslan Training and Research Hospital, Clinic of Surgical Oncology, Ankara, Turkey \\ 2Erciyes University Faculty of Medicine, Department of General Surgical, Kayseri, Turkey \\ 3University of Health Sciences Turkey, Dr. Abdurrahman Yurtaslan Training and Research Hospital, Clinic of Radiation Oncology, Ankara, Turkey \\ 4University of Health Sciences Turkey, Dr. Abdurrahman Yurtaslan Training and Research Hospital, Clinic of General Surgery, Ankara, Turkey \\ 5University of Health Sciences Turkey, Ankara Oncology Health Practice and Research Center, Clinic General Surgical, Ankara, Turkey
}

\section{IIIIIIII| ABSTRACT}

Aim: Rectal cancer is an important cause of cancer-related deaths worldwide (1-2). Although rectal cancers can be diagnosed earlier nowadays due to the development of screening programmes, $18 \%$ of patients have a locally advanced stage at the time of diagnosis (3). Despite the improvements in total mesorectal excision and oncological treatments, the locoregional recurrence rates vary between 6-10\% in rectal cancer patients (4-5).

Method: The data of patients who underwent pelvic exenteration for recurrent rectal cancer in our clinic between January 2015 and December 2019 were retrospectively analysed.

Results: It was found that the patients with lymphovascular invasion (LVI) and perineural invasion (PNI) showed statistically poor survival rates $(\mathrm{p}=0.038 / 0.022)$. Two of the patients had a positive surgical margin and two others had a positive radial margin. There was no statistically significant difference between surgical margin positivity and prognosis ( $>>0.05)$. The mean number of metastatic lymph nodes was $4.0(0-12)$, and the total number of lymph nodes was 12.35 (2-27). There was no statistically significant difference between patients with lymph node metastasis in terms of survival ( $\mathrm{p}=0.079$ ). Seven of the patients $(41.1 \%)$ received systemic treatment before the surgery. It was statistically determined that the patients who received this treatment showed better survival rates $(\mathrm{p}=0.045)$.

Conclusion: It was found that pelvic exenteration had a positive effect on survival and local recurrence in recurrent rectal cancer, and that neoadjuvant therapy increased survival rates.

Keywords: Complication, pelvic exenteration, rectal cancer, recurrence, survival

\section{|||||||||| ÖZ}

Amaç: Rektal kanser tüm dünyada kansere bağlı ölümlerin önemli bir nedenidir (1-2). Günümüzde gelişen tarama programları ile birlikte rektal kanserlere daha erken tanı konulabilse de tanı anında hastaların \%18'i lokal ileri evrededir (3). Total mezorektal eksizyon ve onkolojik tedavilerdeki gelişmelere rağmen rektum kanserli hastalarada lokorejyonel rekurrens oranları \%6-10 arasında değişmektedir (4-5).

Yöntem: Kliniğimizde Ocak 2015-Aralık 2019 tarihleri arasında nüks rektum kanseri nedeniyle pelvik ekzantrasyon yapılan hastaların verileri retrospektif olarak inceledi.

Bulgular: Patoloji raporları incelendiğinde hastaların 10'unda (\%58,8) lenfovasküler invazyon, 10'unda (\%58,8) perinöral invazyon vardı. lenfovasküler invazyon ve perinöral invazyon olan hastaların istatistiksel olarak kötü sağkalım gösterdikleri saptanmıştır ( $\mathrm{p}=0,038 / 0,022)$. Hastaların 2'sinde cerrahi sınır pozitif gelmiş olup, 2'si de radyal sınır pozitifliğiydi. Cerrahi sınır pozitifliği ile prognoz arasında istatistiksel olarak anlamlı fark yoktu $(p>0,05)$. Metastatik lenf nodu sayısı ortalama 4,0 (0-12), toplam lenf nodu sayısı ortalama 12,35 (2-27) olarak bulunmuştur. Lenf nodu metastazı olan hastalarda sağkalım açısından istatistiksel olarak fark bulunmamıştır ( $\mathrm{p}=0,079$ ). Hastaların 7'si (\%41,1) operasyon öncesi sistemik tedavi almıştır. Sistemik tedavi alan hastaların daha iyi sağkalım gösterdiği istatistiksel olarak saptanmıştır $(\mathrm{p}=0,045)$.

Sonuç: Nüks rektum kanserinde pelvik ekzantrasyon ve neoadjuvan tedavinin sağ kalımı artırdığı lokal nüksü azalttığı gözlenmiştir.

Anahtar Kelimeler: Komplikasyon, pelvik ekzantrasyon, rektum kanser, nüks, sağkalım

Address for Correspondence/Yazışma Adresi: Serdar Culcu, MD,

University of Health Sciences Turkey, Dr. Abdurrahman Yurtaslan Training and Research Hospital, Clinic of Surgical Oncology, Ankara, Turkey

E-mail: serdarculcu@gmail.com ORCID ID: orcid.org/0000-0002-1136-1771

Received/Geliş Tarihi: 07.08.2020 Accepted/Kabul Tarihi: 30.09.2020

${ }^{\odot}$ Copyright 2021 by Turkish Society of Colon and Rectal Surgery

Turkish Journal of Colorectal Disease published by Galenos Publishing House. 


\section{Introduction}

Rectal cancer is an important cause of cancer-related deaths worldwide. ${ }^{1,2}$ Although rectal cancers can be diagnosed earlier nowadays due to the development of screening programmes, $18 \%$ of patients have a locally advanced stage at the time of diagnosis. ${ }^{3}$ Despite the improvements in total mesorectal excision and oncological treatments, the locoregional recurrence rates vary between $6 \%-10 \%$ in rectal cancer patients. ${ }^{4,5}$ Invasion to the genitourinary organs occurs in some patients with pelvic recurrence. ${ }^{6,7}$ Pelvic recurrences may present with symptoms such as pain, tenesmus, dysuria and fistula that cannot be controlled by treatment. ${ }^{8}$ The procedure of removing all tumour tissues in order to achieve negative surgical margins in the pelvis is called pelvic exenteration, which significantly contributes to survival in well-selected patient groups with a multidisciplinary approach.

This study aimed to present the outcomes of our patients who underwent pelvic exenteration for locoregional recurrence and to determine the prognostic factors.

\section{Materials and Methods}

Data of patients who underwent pelvic exenteration for recurrent rectal cancer in our clinic between January 2015 and December 2019 were retrospectively analysed. Patients with a pelvic recurrence who developed systemic metastasis were not operated. The site of local recurrence and presence of a distant metastasis in all patients were evaluated by magnetic resonance imaging (MRI) and computed tomography (CT). Preoperative colonoscopy was performed on the patients to locate the tumour site, and cystoscopy was performed on patients with suspected bladder invasion. A total of 17 patients who met these criteria were included in the study. The patients' surgery types and pathology reports, demographic features, length of hospital stay, reasons for re-admission, postoperative complications, postoperative mortality, total and disease-free survival were examined. The radiological examinations (chest X-ray, CT, ultrasonography, endoultrasonography, MRI, positron emission tomography) were reviewed by retrospectively scanning the patients' data. The $8^{\text {th }}$ edition of the TNM classification was used for staging. Ethics committee approval was obtained from our institute. All patients were operated by the same surgical team. Informed consent was obtained from the patients in the preoperative period. The patients underwent bowel cleansing using laxatives and enemas a day before the surgery, and a single-dose prophylactic antibiotic (cefazolin 2 gr) was administered preoperatively. The patients underwent total pelvic exenteration (TPE). TPE is defined as the removal of the genitourinary and reproductive organs including the rectum, distal colon, distal ureters and the lymph nodes draining these, as well as the pelvic peritoneum, and this procedure can be performed in combination with sacrectomy. Afterwards, reconstructions such as lower anastomoses instead of permanent ileostomy, new vagina due to sexual dysfunction, urinary diversion (new bladder or supravesical urinary diversion) and flapgrafts to close the pelvic floor defects can be performed in order to increase the quality of life.

\section{Statistical Analysis}

Data analysis was done using SPSS 11.5 software. For descriptive statistics, quantitative variables were presented as mean \pm standard deviation and median (minimummaximum), and qualitative variables were presented as number of patients (percentage). A survival analysis was performed using the Kaplan-Meier method through qualitative and quantitative variables and the log-rank test was used to determine significant differences between the groups. The level of statistical significance was set at 0.05 .

\section{Results}

Of the patients, 9 (52.9\%) were females and $8(47.1 \%)$ were males. The mean age of the patients was $53.4 \pm 10.1$ years. TPE was performed on all the patients, of whom, 6 (35.3\%) had lower, 7 (41.2\%) had middle, and 4 (23.5\%) had upper rectum localisation, and there was no significant correlation between the survival of the patients and tumour localisation $(p>0.05)$. We had performed a low anterior resection for all patient for the initial surgery and all surgical margins were clear. Of the patients, 12 (70.5\%) had taken neoadjuvant chemoradiotherapy before the initial surgery. When classified according to T-stage, three patients were T2 (11.7\%), five patients were T3 (29.4\%), three patients were $\mathrm{T} 4 \mathrm{a}(11.7 \%)$ and six patients were $\mathrm{T} 4 \mathrm{~b}(35.2 \%)$. It was observed that survival decreased as the T-stage increased $(\mathrm{p}<0.001)$. $\mathrm{N}$ was positive in $11(64.7 \%)$ and $\mathrm{N}$ was negative in 6 (35.3\%) patients. Mortality was found to be high in patients with $\mathrm{N}$ positive results and was statistically significant $(\mathrm{p}<0.05)$. There was no statistical significance in terms of overall survival, disease-free survival and deficit conversion $(p>0.05)$. The mean follow-up duration was 16 months (1-50 months), and considering overall survival, 8 (47.1\%) of 17 patients survived, while 9 (52.9\%) died. The mean survival time was 23.8 months. Three of the patients (11.7\%) developed recurrence, and all recurrences occurred in the pelvic region as a local recurrence. The mean length of hospital stay was $18.1 \pm 11.5$ days. The patient characteristics are shown in Table 1.

The surgical indication was vaginal invasion in 5 (29.4\%) patients, bladder invasion in 11 (64.7\%) patients and uterine 
invasion in 1 (5.8\%) patient. The mean operative time was $200.8 \pm 9.2 \mathrm{~min}$. Of the patients, five developed an infection, one developed an ileal conduit leak and one developed postoperative early bleeding. There was no statistically significant correlation between complication development and survival in the patients $(p>0.05)$. Only the patient who

Table 1. Patient characteristics

\begin{tabular}{|c|c|c|}
\hline Age & \multicolumn{2}{|l|}{$53.47 \pm 10.16$} \\
\hline $\begin{array}{l}\text { Total number of lymph } \\
\text { nodes removed }\end{array}$ & \multicolumn{2}{|l|}{$12.35 \pm 1.77$} \\
\hline $\begin{array}{l}\text { Number of metastatic } \\
\text { lymph nodes }\end{array}$ & \multicolumn{2}{|l|}{$4.00 \pm 0.94$} \\
\hline Survival time (months) & \multicolumn{2}{|l|}{$23.83 \pm 5.07$} \\
\hline \multirow{2}{*}{ Lymphovascular invasion } & Yes & $10(58.8)$ \\
\hline & No & $7(41.2)$ \\
\hline \multirow{2}{*}{ Perineural invasion } & Yes & $10(58.8)$ \\
\hline & No & $7(41.2)$ \\
\hline \multirow{2}{*}{ Recurrence } & Yes & $3(17.6)$ \\
\hline & No & $14(82.4)$ \\
\hline Operative time (min) & \multicolumn{2}{|l|}{$200.88 \pm 9.27$} \\
\hline \multirow{2}{*}{$\begin{array}{l}\text { Preoperative systemic } \\
\text { treatment }\end{array}$} & Yes & $7(41.2)$ \\
\hline & No & $10(58.8)$ \\
\hline $\begin{array}{l}\text { Length of hospital stay } \\
\text { (days) }\end{array}$ & \multicolumn{2}{|l|}{$18.12 \pm 2.80$} \\
\hline \multirow{3}{*}{ Reason for re-admission } & Infection & $7(63.8)$ \\
\hline & ARF & $1(9)$ \\
\hline & $\begin{array}{l}\text { Deterioration of } \\
\text { general condition }\end{array}$ & $3(27.2)$ \\
\hline
\end{tabular}

Min: Minimum, ARF: Acute rheumatic fever developed an ileal conduit leak required reoperation, while the other patients were treated conservatively. Seven patients were readmitted to the hospital for infection, one patient for acute renal failure and three patients for deterioration of the general condition, and the causes of infection were pyuria ${ }^{2}$, intra-abdominal collection ${ }^{4}$ and wound infection. ${ }^{1}$

When the pathology reports were examined, 10 (58.8\%) of the patients had lymphovascular invasion (LVI) and 10 (58.8\%) had perineural invasion (PNI). It was found that the patients with LVI and PNI showed statistically poor survival rates $(\mathrm{p}=0.038 / 0.022)$. Of the patients, two had a positive surgical margin and two had a positive radial margin. There was no statistically significant difference between surgical margin positivity and prognosis $(p>0.05)$. The mean number of metastatic lymph nodes was 4.0 (0-12), and the total number of lymph nodes was 12.35 (2-27). There was no statistically significant difference between patients with lymph node metastasis in terms of survival ( $\mathrm{p}=0.079)$.

Seven of the patients $(41.1 \%)$ received chemoradiotherapy before pelvic exenteration. In accordance with the multidisciplinary team decision, 10 (58.9\%) of the patient did not receive chemoradiotherapy before pelvic exenteration. It was statistically determined that the patients who received this treatment showed better survival rates $(\mathrm{p}=0.045)$.

According to the Kaplan-Meier analysis, the one-year and 2 -year survival rate was $74 \%$ and $26 \%$, respectively. It was statistically shown that the patients who had 12 months or less between the initial operation and pelvic recurrence had worse survival rates than those who had more than 12 months between the initial operation and pelvic recurrence $(\mathrm{p}=0.001)$. Table 2 presents the univariate analysis results that were suggested to affect survival, and the probability of the 1- and 2-year survivals related to these results.

Table 2. Survival analyses

\begin{tabular}{|c|c|c|c|c|c|}
\hline & & 1 year $(\%)$ & 2 years $(\%)$ & Survival time & $\mathrm{p}$ \\
\hline Overall & & 74.0 & 26.9 & $23.83 \pm 5.07$ & - \\
\hline \multirow{2}{*}{ Neoadjuvant therapy } & No & 63.5 & 19.5 & $14.06 \pm 2.77$ & \multirow{2}{*}{0.045} \\
\hline & Yes & 85.7 & 64.3 & $36.64 \pm 7.74$ & \\
\hline \multirow{2}{*}{ LVI } & No & 80.0 & 80.0 & $41.20 \pm 7.87$ & \multirow{2}{*}{0.038} \\
\hline & Yes & 70.0 & 16.7 & $14.70 \pm 2.55$ & \\
\hline \multirow{2}{*}{ PNI } & No & 83.3 & 83.3 & $42.66 \pm 6.69$ & \multirow{2}{*}{0.022} \\
\hline & Yes & 57.1 & 15.2 & $14.32 \pm 2.56$ & \\
\hline \multirow{2}{*}{ Metastatic lymph node } & No & 75.0 & 50.0 & $39.00 \pm 9.52$ & \multirow{2}{*}{0.079} \\
\hline & Yes & 72.7 & 13.6 & $17.18 \pm 3.15$ & \\
\hline \multirow{2}{*}{ Sex } & Female & 55.6 & 27.8 & $21.52 \pm 6.52$ & \multirow{2}{*}{0.507} \\
\hline & Male & 27.8 & 0 & $20.66 \pm 2.37$ & \\
\hline
\end{tabular}

PNI: Perineural invasion, LVI: Lymphovascular invasion 


\section{Discussion}

Pelvic exenteration was first described in 1948 in Brunschwig pelvic malignancies as the en bloc resection of pelvic organs. ${ }^{9}$ Although the mortality rates have been shown to be $20-30 \%$ for many years, this rate has dropped to $<10 \%$ due to the improvements in the surgical technique, intensive care and anaesthesiology. ${ }^{10,11,12,13}$

Rectal cancer surgery is particularly challenging in lower rectal tumours and in patients having a narrow pelvis. Despite all the advances in the surgical technique, the locoregional recurrence rates in colorectal cancer vary between $6 \%-10 \%{ }^{4,5}$ The vast majority of recurrences occur within the first three years after surgery, and when these patients are left untreated, the prognosis varies between 6-8 months. ${ }^{14}$ Patients whose tumour is limited to the pelvis and who do not have distant metastasis are eligible for pelvic exenteration. However, pelvic exenteration can be performed in combination with metastasectomy in a group of patients with resectable distant liver and lung metastases. ${ }^{7,15,16}$ Resectability should be determined by preoperative imaging, including CT, MRI and positron emission tomography. Siatic nerve invasion, external iliac artery invasion, paraaortic lymph node involvement and lymphoedema as a finding of venous or lymphatic infiltration in the lower extremity are considered contraindications for pelvic exenteration. ${ }^{17}$ TPE is defined as the removal of the genitourinary and reproductive organs including the rectum, distal colon, distal ureters and the lymph nodes draining them as well as the pelvic peritoneum and can be performed in combination with sacrectomy. Anterior pelvic exenteration is the resection of the reproductive organs, upper rectum and bladder by preserving the lower part of the rectum. Posterior pelvic exenteration is defined as the resection of the rectum and reproductive organs by preserving the bladder. In our study, all of the patients underwent TPE.

Despite the high mortality and morbidity rates, pelvic exenteration is associated with increased survival in recurrent rectum tumours. In their systemic review, Heriot et al. ${ }^{18}$ showed that pelvic exenteration increased survival with an acceptable morbidity rate and found that the cancer-specific survival rate was increased and local recurrence was significantly reduced by neoadjuvant or adjuvant chemoradiotherapy. Domests et al. ${ }^{19}$ found a 30day mortality rate of 3.6\%, 3-year disease-free survival rate of $52.2 \%$ and 3 -year overall survival rate of $75.1 \%$. In our study, the 30-day mortality rate was $5.8 \%, 1$ - and 2-year overall survival rates were $74 \%$ and $26.4 \%$, respectively. Our 1- and 2-year disease-free survival rates were $67.3 \%$ and $40.4 \%$, respectively. We think that the reason for the lower survival time in our study is due to the inclusion of only patients who developed recurrences, the short followup period and small number of patients.

In the literature, many factors such as positive surgical margin, neoadjuvant therapy, number of metastatic lymph nodes, lymphovascular invasion and perineural invasion have been identified to be effective in determining survival after pelvic exenteration, and among these, R0 resection has been shown to be the most important prognostic factor. ${ }^{19,20,21,22,23}$ However, in their study, Kakuda et al. ${ }^{24}$ found no difference between patients who underwent R1 resection and those who underwent $\mathrm{R} 0$ resection in terms of overall survival rates (23-18 months $\mathrm{p}=0.67$ ). In our study, the radial surgical margin was positive in two patients and the effect of surgical margin positivity on survival could not be demonstrated ( $p>0.05)$. While the effect of lymph node positivity on survival has been demonstrated in many studies $22,23,24,25$, the effect of lymph node positivity on survival could not be demonstrated in the present study. We think that the reason for this is our small number of patients and short follow-up time. In our study, the factors affecting survival rates were found to be the time from the initial operation to pelvic recurrence, lymphovascular invasion, perineural invasion and neoadjuvant therapy $(\mathrm{p}=0.001$, $\mathrm{p}=0.038, \mathrm{p}=0.022, \mathrm{p}=0.045$ ).

In patients undergoing pelvic exenteration, a second surgery may be required for reasons such as adhesion due to primary surgery and fibrosis due to radiotherapy, resulting in the prolongation of the operative time, increase in postoperative complications and prolonged length of hospital stay. In a systemic review including 23 studies, the researchers found the complication rates after pelvic exenteration as 37\%$100 \% .{ }^{26}$ In our study, the complication rate was $41.1 \%$, and most of these patients developed wound infection. Reoperation was performed on one patient for postoperative bleeding and in one patient for ileal conduit leak. In the literature, there are prolonged operative times. ${ }^{20}$ In our study, the mean operative time was recorded as $200.88 \pm 9.27$ min. We think that the operative time in this study is shorter than those reported in the literature because all the surgical interventions were performed by the same team of experienced professionals.

Radiological studies are unable to determine whether invasion to the genitourinary organs is due to inflammation or tumour invasion in $20 \%-56 \%$ of patients undergoing pelvic exenteration..$^{27,28}$ In our series, $29.4 \%$ of the patients did not show tumour invasion to the genitourinary organs.

Although pelvic exenteration provides a high level of local control in recurrent rectal cancers, the rate of recurrence after pelvic exenteration ranges from $4.8 \%-61 \%$ (average $22 \%$ ) in the literature. ${ }^{26}$ In our study, three of all patients developed local recurrence (11.7\%), which is consistent with the literature. 


\section{Conclusion}

In conclusion, it was found that pelvic exenteration had a positive effect on survival and local recurrence in recurrent rectal cancer, and that neoadjuvant therapy increased survival rates.

\section{Ethics}

Ethics Committee Approval: University of Health Sciences Turkey, approval was obtained from the Ethics Committee of Ankara Dr. Abdurrahman Yurtaslan Oncology Health Application and Research Center (decision no: 95, date: 27.05.2020).

Informed Consent: Obtained.

Peer-review: Externally and internally peer reviewed.

\section{Authorship Contributions}

Concept: S.C., C.Y., M.O.K., F.G., E.G., B.A., L.D., Design: S.C., C.Y., M.O.K., F.G., E.G., B.A., L.D., Data Collection or Processing: S.C., C.Y., M.O.K., F.G., E.G., B.A., L.D., Analysis or Interpretation: S.C., C.Y., M.O.K., F.G., E.G., B.A., L.D., Literature Search: S.C., C.Y., M.O.K., F.G., E.G., B.A., L.D., Writing: S.C., C.Y., M.O.K., F.G., E.G., B.A., L.D.

Conflict of Interest: No conflict of interest was declared by the authors.

Financial Disclosure: The authors declared that this study received no financial support.

\section{References}

1. Canadian Cancer Society/NationalCancer Institute of Canada. Canadian Cancer Statistics 2009, Toronto, Canada, 2009. Available from: https:// www.cancer.ca/en/cancer-information/cancer-101/canadian-cancerstatistics-publication/past-editions-canadian-cancer-statistics/ / media/98DB59DCE6EE45ADABFE978EC3DBD4AD.ashx

2. NationalCancer Information Center. Cancerinformation service [Internet]. Goyang (KR): NationalCancer Information Center; c2011 [cited 2012 Jun 5]. Availablefrom: http://www.cancer. go.kr/ncic/cics_f/01/014/index. html.

3. O'Connell JB, Maggard MA, Liu JH, Liu JH, Etzioni DA, Ko CY. Are survival rates different for young and older patients with rectal cancer? Dis Colon Rectum 2004:47:2064-2069.

4. Bakx R, Visser O, Josso J, Meijer S, Slors JF, vanLanschot JJ. Man ᄀagement of recurrentrectalcancer: a populationbasedstudy in greater Amsterdam. World J Gastroenterol 2008;14:6018-6023.

5. Sebag-Montefiore D, Stephens RJ, Steele R, Monson J, Grieve R, Khanna S, Quirke P, Couture J, de Metz C, Myint AS, Bessell E, Griffiths G, Thompson LC, Parmar M. Preoperative radiotherapy versus selective post $\neg$ operative chemoradiotherapy in patients with rectal cancer (MRC CR07 and NCICCTG C016): a multicentre, randomisedtrial. Lancet 2009;373:811-820.

6. Pilipshen SJ, Heilweil M, Quan SH, Sternberg SS, Enker WE. Patıterns of pelvic recurrence following definitive resections of rectal cancer. Cancer 1984:53:1354-1362.

7. McDermott FT, Hughes ES, Pihl E, Johnson WR, Price AB. Local recurrence after potentially curative resection forrectal cancer in a series of 1008 patients. Br J Surg 1985;72:34-37.
8. Ito Y, Ohtsu A, Ishikura S, Boku N, Nihei K, Ogino T, Ikeda H. Effi-cacy of chemoradiotherapy on painrelief in patients with intraᄀpelvic recurrence of rectal cancer. Jpn J Clin Oncol 2003;33:180-185.

9. Brunschwig A. Complete excision of pelvicviscera for advancedc arcinoma. Cancer 1948;1:177-183.

10. Boey J, Wong J, Ong GB. Pelvic exenteration for locally advanced colorectal carcinoma. Ann Surg 1982;195:513-518.

11. Lopez MJ, Kraybill WG, Downey RS, Johnston WD, Bricker EM. Exenterative surgery for locally advanced rectosigmoid cancers. Is it worthwhile? Surgery 1987;102:644-651.

12. Jimenez RE, Shoup M, Cohen AM, Paty PB, Guillem J, Wong WD. Contemporary outcomes of total pelvic exenteration in treatment of colorectal cancer. Dis Colon Rectum 2003;46:1619-1625.

13. Law WL, Chu KW, Choi HK. Total pelvic exenteration for locally advanced rectal cancer. J Am Coll Surg 2000;190:78-83.

14. Palmer G, Martling A, Cedermark B, Holm T. A population-based study on the management and outcome in patients with locally recurrent rectal cancer. Ann Surg Oncol 2007;14:447-454.

15. Pawlik TM, Skibber JM, Rodriguez-Bigas MA. Pelvic exentera-tion for advanced pelvic malignancies. Ann Surg Oncol 2006;13:612-623.

16. Mirnezami AH, Sagar PM, Kavanagh D, Witherspoon P, Lee P, Winter D. Clinical algorithms for the surgical management of lo-cally recurrent rectal cancer. Dis Colon Rectum 2010;53:1248-1257.

17. Moriya Y, Akasu T, Fujita S, Yamamoto S. Total pelvic exenteration with distal sacrectomy for fixed recurrent rectal cancer inthe pelᄀvis. Dis Colon Rectum. 2004:47:2047-2053.

18. Heriot AG, Tekkis PP, Darzi A, Mackay J. Surgery for local recurrence of rectal cancer. Colorectal Dis 2006;8:733-747.

19. Domests, Colquhoun Ph, Taylor B, Izawa JI, House AA, Luke PPW. Total pelvic exenteration for rectal cancer: out come sand prognostic factors. Can J Surg 2011;54:387-393.

20. Ferenschild FT, Vermaas M, Verhoef C, Ansink AC, Kirkels WJ, Eggermont AMM, de Wilt JHW. Total pelvic exenteration for primary and recurrent malignancies. World J Surg 2009;33:1502-1508.

21. Hsu TW, Chiang FF, Chen MC, Wang HM. Pelvic exenteration for men with locally advanced rectal cancer: a morbidity analysis of complicated cases. Asian J Surg 2011;34:115-120.

22. Bernstein TE, Endreseth BH, Romundstad P, Wibe A; Norwegian Colorectal Cancer Group. Circumferential resection margin as a prognostic factor in rectal cancer. Br J Surg 2009;96:1348-1357.

23. Kelly ME, Winter DC; Pelv Ex Collaborative. Surgical and survival outcomes following pelvic exenteration for locally advanced primary rectal cancer: results from an international collaboration. Ann Surg 2019;269: 315-321.

24. Kakuda JT, Lamont JP, Chu DZ, Paz IB. The role of pelvic exenteration in the management of recurrent rectal cancer. Am J Surg 2003;186:660-664.

25. Ishiguro S, Akasu T, Fujita S, Yamamoto S, Kusters M, Moriya Y. Pelvic exenteration for clinical T4 rectal cancer: oncologic outcome in 93 patients at a single institution over a 30-year period. Surgery 2009;145:189-195.

26. Yang T, Morris D, Chua T. Pelvic exenteration for rectal cancer: a systematic review. Dis Colon Rectum 2013;56:519-531.

27. Hida J, Yasutomi M, Maruyama T, Akihiro Nakajima M.D., Uchida T, Wakano T, Tokoro T, Fujimoto K. Results from pelvic exenteration for locally advanced colorectal cancer with lymphnode metastases. Dis Colon Rectum 1998;41:165-168.

28. Lehnert T, Methner M, Pollok A, Schaible A, Hinz U, Herfarth C. Multivisceral resection for locally advanced primary colon and rectal cancer: an analysis of prognostic factors in 201 patients. Ann Surg 2002;235:217-225 